\title{
Relationship between Asian monsoon strength and transport of surface aerosols to the Asian Tropopause Aerosol Layer (ATAL): interannual variability and decadal changes
}

\author{
Cheng Yuan ${ }^{1,2}$, William K. M. Lau ${ }^{2,3}$, Zhanqing $\mathbf{L i}^{2,3}$, and Maureen Cribb ${ }^{2}$ \\ ${ }^{1}$ School of Atmospheric Sciences, Nanjing University, Nanjing, 210023, China \\ ${ }^{2}$ Earth System Science Interdisciplinary Center, University of Maryland, College Park, MD 20740, USA \\ ${ }^{3}$ Department of Atmospheric and Oceanic Sciences, University of Maryland, College Park, MD 20740, USA
}

Correspondence: Zhanqing Li (zhanqing@umd.edu) and William K. M. Lau (wkmlau@umd.edu)

Received: 25 July 2018 - Discussion started: 18 September 2018

Revised: 1 December 2018 - Accepted: 15 January 2019 - Published: 12 February 2019

\begin{abstract}
In this study, we have investigated the interannual variability and the decadal trend of carbon monoxide (CO), carbonaceous aerosols (CA) and mineral dust in the Asian Tropopause Aerosol Layer (ATAL) in relation to varying strengths of the South Asian summer monsoon (SASM) using MERRA-2 reanalysis data (2001-2015). Results show that during this period, the aforementioned ATAL constituents exhibit strong interannual variability and rising trends connected to the variations of the strength of SASM. During strong monsoon years, the Asian monsoon anticyclone (AMA) is more expansive and shifted northward compared to weak years. In spite of the effect of quenching of biomass burning emissions of $\mathrm{CO}$ and CA by increased precipitation, as well as the removal of CA and dust by increased washout from the surface to the mid-troposphere in monsoon regions, all three constituents are found to be more abundant in an elongated accumulation zone in the ATAL, on the southern flank of the expanded AMA. Enhanced transport to the ATAL by overshooting deep convection is found over preferred pathways in the Himalayan-Gangetic Plain (HGP) and the Sichuan Basin (SB). The long-term positive trends of ATAL CO and CA are robust, while the ATAL dust trend is weak due to its large interannual variability. The ATAL trends are associated with increasing strength of the AMA, with earlier and enhanced vertical transport of ATAL constituents by enhanced overshooting convection over the HGP and $\mathrm{SB}$ regions, outweighing the strong reduction of $\mathrm{CA}$ and dust from the surface to the mid-troposphere.
\end{abstract}

\section{Introduction}

The discovery from satellite lidar observations of the Asian Tropopause Aerosol Layer (ATAL) - a planetary-scale aerosol layer situated $13-18 \mathrm{~km}$ above sea level, spanning vast regions from the Middle East, south and east Asia to the western Pacific during the Asian summer monsoon (ASM) has spurred active research on the composition $\left(\mathrm{H}_{2} \mathrm{O}\right.$, chemical gaseous and aerosol species) and the relationship between the ATAL and the Asian monsoon anticyclone (AMA), and climate change (Fadnavis et al., 2013; Lelieveld et al., 2018; Li et al., 2005; Randel and Park, 2006; Randel et al., 2010; Thomason and Vernier, 2013; Vernier et al., 2011, 2015, 2017; Yu et al., 2015). Previous studies have shown that deep convection in the tropics and volcanic eruptions can transport water vapor and surface pollutants including carbon monoxide $(\mathrm{CO})$, sulfur dioxide $\left(\mathrm{SO}_{2}\right)$ and carbonaceous aerosols (CA) over source regions such as northern India and southwest China into the upper troposphere and lower stratosphere (UTLS) (Kremser et al., 2016; Li et al., 2005; Neely et al., 2014; Vogel et al., 2015). Other studies also reported that the ASM system can act as a conduit for these chemicals and aerosols convectively transported to the UTLS region (Bergman et al., 2013, 2015; Bourassa et al., 2012; Garny and Randel, 2016).

Recent results from lidar observations, high-altitude balloon sounding data and model simulations have shown a relatively higher concentration of chemicals and aerosols in the UTLS during the boreal summer, indicating effective vertical transport by the ASM (Babu et al., 2011; Kulka- 
rni et al., 2008; Tobo et al., 2007; Yu et al., 2017). It has been suggested that lifting tropospheric air parcels into the UTLS is associated with the establishment of the AMA during the peak phase (July-August) of the ASM (Gettelman et al., 2004; Park et al., 2007, 2009; Ploeger et al., 2015; Randel and Park, 2006; Randel et al., 2010). Upon entering the UTLS, gaseous chemical species and aerosols are advected anticyclonically and confined within the influence region of the AMA, forming the ATAL (Lau et al., 2018). Pan et al. (2016) found that CO can be lifted into the UTLS by deep convection over the southern flank of the Tibetan Plateau (TP) during boreal summer, and suggested that the dynamics of monsoon subseasonal variability may play an important role in this. Yu et al. $(2015,2017)$ found that up to $15 \%$ of Northern Hemisphere UTLS aerosols came from vertical transport over the TP region via the ATAL during the ASM. Besides the Himalayan foothills, another transport pathway, located over central and southwestern China, has also been reported (Fadnavis et al., 2013). While UTLS transport processes have been shown to be closely related to the variability in the ASM, the mechanisms of UTLS transport processes and formation of the ATAL are not yet fully understood. A few recent studies have begun to examine the relationship between the ATAL and the ASM on seasonal to subseasonal timescales (Pan et al., 2016; Lau et al., 2018). However, physical processes linking the ATAL and ASM on interannual and longer timescales are still unknown.

To recap, Lau et al. (2018) found a planetary-scale "double-stem chimney cloud" (DSCC) encompassing two "stem regions": one over the Himalayan-Gangetic Plain (HGP) and the other over the Sichuan Basin (SB), where surface pollutants in Asian monsoon regions are pumped up to the UTLS during the boreal summer monsoon season, forming the ATAL via turbulent mixing and advection by the large-scale anticyclonic circulation of the AMA. While heavy monsoon rain strongly removes aerosols by washout in the lower troposphere and near the surface, lofting by penetrative convection, anchored and amplified by orographic uplifting in the stem regions, can efficiently transport ambient aerosols in the middle and upper troposphere to the UTLS. They also found that the origin and variability of ATAL constituents, specifically CO, CA and dust, are closely linked to the seasonal development and intrinsic intraseasonal (2030 days) oscillations of the DSCC. This is a follow-up study to gain further new insights into physical processes leading to the ATAL variability on interannual to decadal timescales.

\section{Data and analysis methods}

\section{Methods}

Our study uses daily data from NASA's Modern Era Retrospective analysis for Research and Applications, Version 2 (MERRA-2) (Gelaro et al., 2017). This dataset is gener- ated using the latest version of the Goddard Earth Observing System Model, Version 5 (GEOS-5), global data assimilation system, including the assimilation of aerosol optical depth (AOD) from MODerate resolution Imaging Spectroradiometer (MODIS) and Multi-angle Imaging SpectroRadiometer (MISR) satellite retrievals. The MERRA-2 resolution is $0.5^{\circ} \times 0.625^{\circ}$ latitude-longitude with 72 vertical levels (Molod et al., 2015). It provides 3-hourly global conventional meteorological data, i.e., temperature, winds, moisture, and precipitation, as well as the concentrations of chemical gases and various aerosol species. All the processes of aerosol transport, deposition, microphysics, and radiative forcing are included. MERRA-2 provides observation-based precipitation data; the product of precipitation has been assimilated and validated by both TRMM and GPCP (Reichle et al., 2017). Aerosol emissions from biomass burning and wildfires are derived from the satellite Quick Fire Emission Dataset (QFED; Darmenov and da Silva, 2013). The anthropogenic aerosol emission inventory is from the annual historical AeroCom Phase II (Diehl et al., 2012), up to the mid2000s depending on the availability of emission data for various gases and aerosol species (Randles et al., 2017). Beyond that the anthropogenic aerosol emissions are not updated. As such, the direct effects due to changes in anthropogenic source emission cannot be assessed using MERRA-2. The implication of this for our results will be discussed in the Summary in Sect. 4.

In this study, we choose $\mathrm{CO}, \mathrm{CA}$ that include $\mathrm{BC}$ and organic carbon (OC) and dust as tracers for diagnosing transport. Abundant quantities of CA and dust, found during the boreal summer season in the ASM region from local emissions and remote transport, could have strong impacts on the evolution of the Asian monsoon (Lau and Kim, 2006; Lau et al., 2006; Lau, 2014; Meehl et al., 2008; Park et al., 2009; Vinoj et al., 2014). CO is a representative pollution tracer commonly used in previous studies of UTLS transport (Pan et al., 2016; Santee et al., 2017). This chemical gas is mainly emitted from biomass burning and industrial pollution. Black carbon (BC) is a part of CA and is one of the main by-products emitted from anthropogenic sources, as well as from natural wildfire activities. OC, also a part of CA, derived mostly from biomass burning and wildfires, is more abundant than BC in ASM regions (Chin et al., 2002), and has been detected in the ATAL (Yu et al., 2015). CA are not evenly distributed in the atmosphere like $\mathrm{CO}$ and are subject to wet and dry deposition. Emission sources of $\mathrm{CO}$ and $\mathrm{CA}$, such as from local biomass burning, can also be quenched by heavy monsoon rain (Lau, 2016; Lau et al., 2018). On the other hand, dust aerosols in ASM come from desert regions via longrange transport rather than from local emissions (Lau et al., 2008; Lau, 2014). This horizontal transport depends on the development of monsoon westerlies which extend from near the surface to the mid-troposphere (Gautam et al., 2009b; Lau et al., 2006; Zhang et al., 1996). While monsoon rain washout during the peak monsoon season (July-August) re- 
moves much of the coarse dust particles in and below clouds, ambient fine dust particles $(<0.2 \mu \mathrm{m})$ in and above clouds are lifted into the ATAL by penetrative deep convection anchored to the stem regions of the DSCC (Lau et al., 2018).

\section{Results}

\subsection{Strong vs. weak monsoon}

Figure 1a shows the climatological precipitation distribution and establishment of the AMA over the greater ASM region during the boreal summer monsoon season from July to August. The pronounced AMA with strong anticyclonic circulation (tropical easterlies and extratropical westerlies) develops in conjunction with heavy rainfall over the Western Ghats of India, the Indo-Gangetic Plain (IGP) of northern India, the Bay of Bengal, eastern China and the southeast Asian region (Fig. 1a). Additionally, the interannual variability of aerosols can be strongly affected by precipitation over the IGP region (Gautam et al., 2009a; Kim et al., 2016; Sanap and Pandithurai, 2015). In this study, we choose the domain $\left(5-30^{\circ} \mathrm{N}\right.$, $\left.70^{\circ} \mathrm{N}-95^{\circ} \mathrm{E}\right)$ to define strong vs. weak South Asian summer monsoon (SASM) years. This region is known to be subject to heavy monsoon precipitation and orographic forcing, which facilitates uplifting of water vapor and atmospheric constituents by penetrative deep convection to the UTLS region and above (Houze et al., 2007; Medina et al., 2010; Pan et al., 2016). The annual mean precipitation intensity for each year from 2001 to 2015 over the selected domain during the peak monsoon season (July-August) was calculated and used to represent the monsoon strength (Lau et al., 2000). Strong interannal variability and a robust increasing trend can be seen during this data period (Fig. 1b). This trend has been validated by observational data (Fig. S1 in the Supplement), and a similar increasing decadal trend of the SASM has been reported in previous studies (Jin and Wang, 2017). To focus on interannual variability, we first detrended the rainfall time series, and then defined strong vs. weak monsoon years based on the detrended time series (Fig. 1c). Strong (weak) monsoon years were selected when the mean rainfall was above (below) 1 standard deviation. Based on this procedure, four strong monsoon years $(2007,2010,2011$ and 2013; denoted as "SM") and three weak monsoon years (2002, 2014 and 2015; denoted as "WM") were identified. Composite mean distributions of monsoon meteorology, as well as aerosol loading transport, and ATAL variability were carried out for SM and WM, respectively, based on the detrended data. Henceforth, the term "anomaly" in the following parts refers to the difference between SM and WM composites (SM minus WM).

During SM, the AMA is stronger and more expansive than in WM, as evident in the corresponding $100 \mathrm{hPa}$ geopotential height fields over the region (Fig. 2a). The AMA in SM is wavier over the extratropics and appears to have shifted

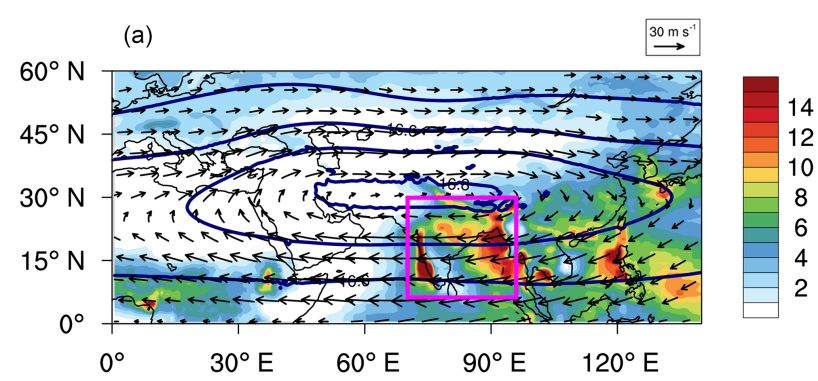

(b)
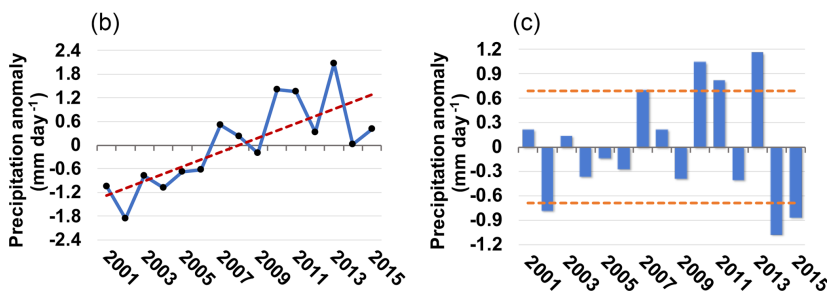

Figure 1. Climatological mean ASM features associated with the AMA showing (a) the spatial distribution of winds (arrows, in $\mathrm{m} \mathrm{s}^{-1}$ ), geopotential height at $100 \mathrm{hPa}$ (solid contours, in km) and rainfall (colored background, in $\mathrm{mm} \mathrm{day}^{-1}$ ) during July-August of 2001-2015. The pink box $\left(5-30^{\circ} \mathrm{N}, 70^{\circ} \mathrm{N}-95^{\circ} \mathrm{E}\right)$ outlines the domain selected for calculating the precipitation intensity. (b) Time series of the precipitation anomaly from 2001 to 2015 (with the trend line in red). (c) The detrended distribution (with standard deviations in orange).

poleward, indicating a stronger extratropical influence on the AMA compared to WM years. The enhanced AMA in SM occurs in conjunction with anomalous warming in the atmosphere above the TP and cooling in the lower stratosphere, as well as stronger anticyclonic circulation with anomalous westerlies at $35^{\circ} \mathrm{N}$ and easterlies at $20^{\circ} \mathrm{N}$ between 250 and $100 \mathrm{hPa}$, together with an elevated tropopause (Fig. 2b). Cooling found near the surface is due to increased precipitation and cloudiness during SM. These are well-known features of a strong SASM (Huang and Sun, 1992; Lau et al., 2018; Randel and Park, 2006; Rodwell and Hoskins, 1996; Wang, 2006; Wu et al., 2007).

Figure 3 shows spatial distributions of climatological and anomalous rainfall, AOD and low-level winds during July-August. Climatologically (Fig. 3a), heavy rain $\left(>6 \mathrm{~mm} \mathrm{day}^{-1}\right)$ is found over the Western Ghats, the Bay of Bengal and the southeast Asian region. AOD is high over northern Africa, the Middle East, and the Arabian Sea due to dust emissions from deserts and transport via the southwesterly monsoon flow to the Indian subcontinent. During SM years, enhanced precipitation is seen over the ASM land and adjoining oceanic regions of the Arabian Sea and the Western Indo-Pacific. The most pronounced increase is found over the Western Ghats of India and the HGP. Over east Asia, the presence of an elongated and southwest-northeastoriented dipole-like precipitation anomaly, together with the increased anticyclonic low-level circulation, is indicative of a 
northward migration of the Mei-yu rain belt, associated with a strengthening of the subtropical high (Tao et al., 2001; Lau et al., 2000) (Fig. 3b). Stronger low-level anomalous westerlies and easterlies are found over the Arabian Sea and the equatorial western Pacific, respectively. During SM, AOD is overall lower over the Indian subcontinent and the tropical western Pacific due to stronger precipitation washout. Positive anomalous AOD is found over the Middle East and central Asia. The former is related to increase surface emission of dust, and the latter is likely due to increased biomass burning emissions (Fig. S2). Over east Asia, an increase in AOD is found, possibly due to increased CA from biomass burning (Figs. 3b, S1). Note that higher AOD and enhanced precipitation appear to coexist over northeastern China. This may be due to the aerosol swelling effect, which is related to relatively higher relative humidity induced by the enhanced Mei-yu rain belt during the moist summer monsoon season (Qu et al., 2016). Another possibility is that increased remote transport and uplifting above clouds by deep convection increased CA loading in the mid-troposphere to upper troposphere, even as CA in lower layers are removed by strong precipitation washout (Lau et al., 2018).

During SM, the $100 \mathrm{hPa}$ geopotential height shows higher pressure over the subtropics and midlatitude regions (25$40^{\circ} \mathrm{N}$ ), with centers over the eastern (east Asia) and western end (northern Africa) portions of the climatological AMA (see Fig. 2a). These high-pressure centers appear to be associated with a Rossby wave train pattern spanning the extratropics and the subtropics across Eurasia (Lau and Kim, 2012; Wang et al., 2008). Increased CO loading can be seen over three regions, i.e., northern Africa, the TP and centralnortheastern China in an elongated "accumulation zone" along the southern flank of the expanded AMA (Fig. 4b). For $\mathrm{CA}$, similar centers of action can be found, except that regions of enhanced CA loading are more expansive and cover large parts of the AMA. Stronger concentration of CA is also seen along the southern flank of the expanded AMA, consistent with stronger easterly wind transport during SM years (Figs. 4d, 2b) (Lau et al., 2018). Higher loading of CO and CA can be attributed not only to the deformation of the AMA, but also to the enhancement of surface emission during SM years. As shown in the next subsection, during SM years, higher loadings of both CO and CA in the UTLS are found near regions of enhanced emissions only when there is increased vertical motion from deep convection (Fig. S2). Similar to CA, more dust is also evident over the accumulation zone spanning northern Africa, the Middle East, the TP and east Asia during SM (Fig. 4f).

\subsection{Zonal and meridional cross sections}

In this subsection, we examine the changes in the ATAL structure along the axis of the DSCC $\left(25-35^{\circ} \mathrm{N}\right)$ during SM and WM years. We begin with the structural changes in the vertical motion field under the influence of the AMA (a)

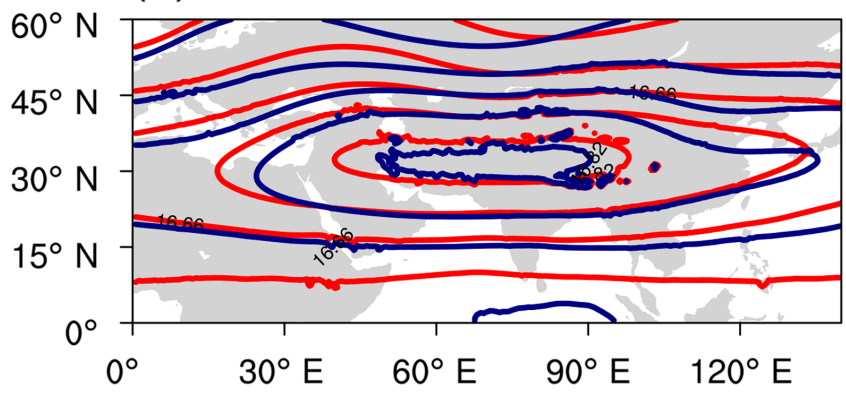

(b)

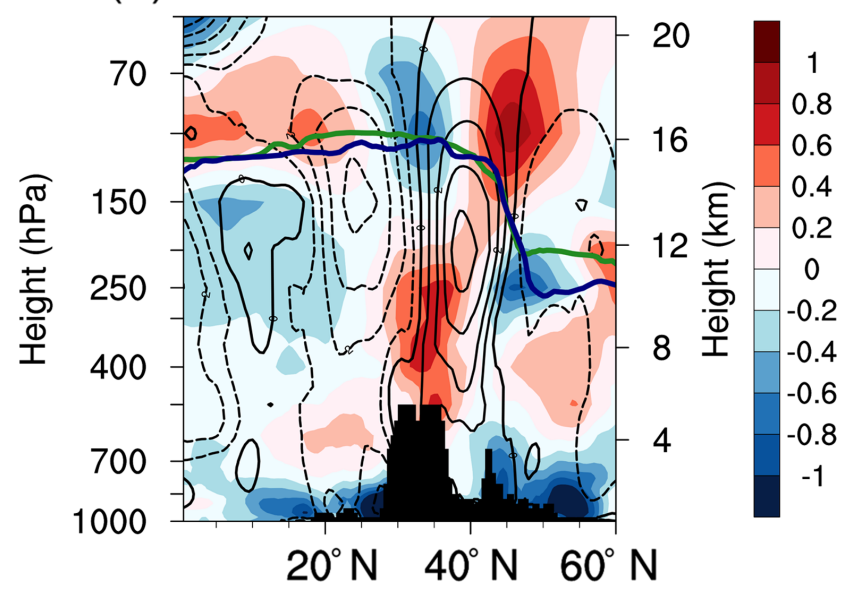

Figure 2. (a) $100 \mathrm{hPa}$ geopotential height (in $\mathrm{km}$ ) in strong (weak) monsoon years during July-August is shown in red (blue). (b) Latitude-height cross section of temperature anomalies (color shaded, in $\mathrm{K}$ ), zonal wind anomalies (contour lines, in $\mathrm{ms}^{-1}$ ) between strong and weak monsoon years ("strong" minus "weak") and tropopause height (thick lines) in strong monsoon years (green) and weak monsoon years (blue) over the Indian subcontinent (80$85^{\circ} \mathrm{E}$ ) during July-August.

(Fig. 5d). During SM years, overall enhanced anomalous ascending motions are found over the western sector (east of $85^{\circ} \mathrm{E}$ ), while anomalous descending motions are found over the eastern sector (west of $85^{\circ} \mathrm{E}$ ) of the AMA. In the western sector, two regions with strong vertical motion are found clustered over northern Africa and the Middle East $\left(15-50^{\circ} \mathrm{E}\right)$ and over the foothills of the HGP $\left(70-85^{\circ} \mathrm{E}\right)$ with an anomalous ascent extending above $100 \mathrm{hPa}$ in both regions. Over the western sector and embedded within a large region of overall anomalous descent, an enhanced ascent is also found over east Asia around $105-115^{\circ} \mathrm{E}$ reaching above $100 \mathrm{hPa}$. As noted earlier (see Fig. 3c), during SM years, the Mei-yu rain belt is shifted northward, leaving behind mostly anomalous descending motions in this latitudinal zone. However, a moderately increased ascent is found over western central China $\left(105-120^{\circ} \mathrm{E}\right)$ from the eastern foothills of the TP and the SB, collocating with the southern tip of the northward-shifted Mei-yu rain belt. These three 

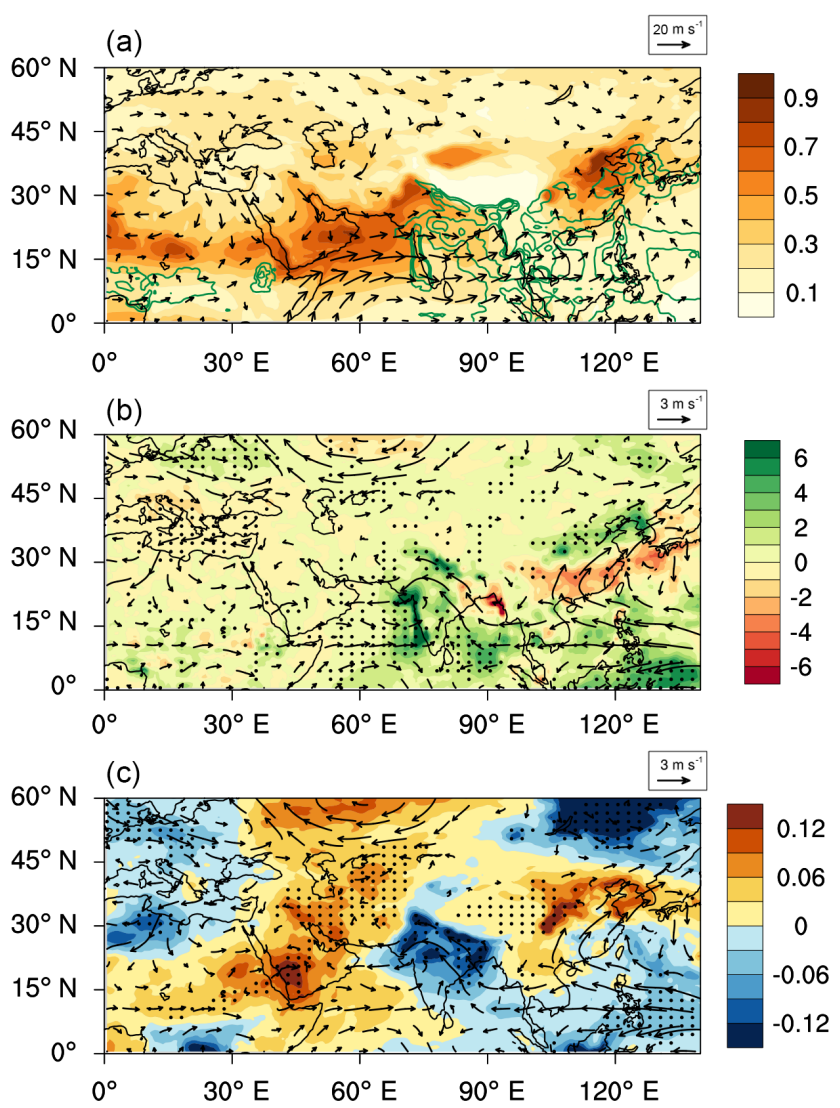

Figure 3. (a) Spatial distributions of climatological AOD during July to August, superimposed with precipitation (only those $>6 \mathrm{~mm} \mathrm{day}^{-1}$ are shown) and $850 \mathrm{hPa}$ wind (arrows, in $\mathrm{ms}^{-1}$ ). (b) Spatial distributions of anomalous ("strong" minus "weak") precipitation $\left(\mathrm{mm} \mathrm{day}^{-1}\right)$ and $850 \mathrm{hPa}$ wind (arrows, in $\mathrm{m} \mathrm{s}^{-1}$ ). (c) is same as (b) except the patter is showing anomalous AOD and $850 \mathrm{hPa}$ wind (arrows, in $\mathrm{m} \mathrm{s}^{-1}$ ). Dots represent data points with a significance $>95 \%$.

regions of anomalous ascent play essential roles in the distribution of chemical gases and aerosols species in the ATAL.

During SM years, the CO concentration is generally increased in the ATAL (Fig. 5a), consistent with the enhanced advection by the strengthened easterlies at the southern flank of the AMA. Three centers of anomalous high CO concentration in the UTLS (200-100 hPa) over northern Africa, the TP and east Asia (identified in Fig. 4b) stand out. These centers appear to be connected via stems of high $\mathrm{CO}$ related to the aforementioned three regions of anomalous ascent. The large reduction in $\mathrm{CO}$ near the surface over east Asia may be related to the quenching of emission sources by increased precipitation over this region (Figs. 5a, S2b). For CA, the pattern of anomalies is similar to the pattern of $\mathrm{CO}$, with overall increased loading in the UTLS, and three action centers connected by stems of high CA to the surface (Fig. 5b). The increase in near-surface CA over desert regions (east of $70^{\circ} \mathrm{E}$ ) is consistent with increased surface emissions (Fig. S2d). The reduction in $\mathrm{CA}$ in the monsoon region (west of $70^{\circ} \mathrm{E}$ ) is likely due to stronger precipitation washout during SM. Likewise, during SM, severely suppressed dust is found near the surface up to the mid-troposphere in the stem over the HGP $\left(60-100^{\circ} \mathrm{E}\right)$, associated with washout by the increased precipitation (Figs. 5c, 3b). Similar to $\mathrm{CO}$ and $\mathrm{CA}$, dust reduction can also be seen in the middle and lower troposphere over eastern China $\left(105-135^{\circ} \mathrm{E}\right)$ because of the enhanced rainout process. Due to the increased near-surface wind, dust loading is increased over the Middle East $\left(30-70^{\circ} \mathrm{E}\right)$ but decreased over northern Africa. Sources of dust contributing to the increased dust loading in the UTLS (above $200 \mathrm{hPa}$ ) seem to mainly come from the Middle East and west Asia, with some contribution from the eastern TP, abutting the SB region.

Two meridional cross sections (80-85 and $\left.100-105^{\circ} \mathrm{E}\right)$, for the HGP (Fig. 6) and the SB (Fig. S3) regions, respectively, have been examined. Because of a similarity in patterns, only the HGP region (Fig. 6) is discussed here. Ascending motions during SM years over the HGP region near the foothills and top of the TP are enhanced and weakened locally in the vicinity of $20^{\circ} \mathrm{N}$, associated with the enhancement and northward shifting of the AMA (Fig. 6d). Additional increased ascending motions are south of $20^{\circ} \mathrm{N}$, likely with the increased precipitation over southern India and the northern Indian Ocean (see Fig. 3b). A dipole pattern featuring increased $\mathrm{CO}$ over the top of the TP from 500 to $70 \mathrm{hPa}$ at the northern edge of the climatological CO maxima was coupled with reduced $\mathrm{CO}$ south of $20^{\circ} \mathrm{N}$; Fig. $6 \mathrm{a}$ again indicates that more $\mathrm{CO}$ was lifted into the UTLS by the enhanced vertical motion associated with the northward shift of the AMA during SM years. The reduction of CO in the lower troposphere and near the surface in the extratropics $\left(40-58^{\circ} \mathrm{N}\right)$ is likely related to the quenching of emission sources of biomass burning over the region (Fig. S2b). Similar to $\mathrm{CO}$, more CA are transported and enter the UTLS via the HGP stem in SM years, and the increased loading is more expansive than $\mathrm{CO}$ spanning $25-60^{\circ} \mathrm{N}$, from 500 to $50 \mathrm{hPa}$. This may be due to an increase in biomass burning emission sources over northern central Asia (Figs. 6b and S2d). Associated with the northward shifting of the AMA, CA concentrations below $100 \mathrm{hPa}$ over the tropical region are substantially reduced. During SM years, dust is mostly reduced over the regions from the surface to the upper troposphere. Increase uplifting of dusts into the UTLS by anomalous ascending motions is found over the TP and the Taklamakan desert $\left(35-42^{\circ} \mathrm{N}\right)$. The pronounced reduction in CA and dust loadings over the foothills of the TP and the Indian subcontinent is due to wet scavenging effect by the enhanced rainfall over the region. For the SB stem region (Fig. S3), the pattern of anomalous concentrations of $\mathrm{CO}, \mathrm{CA}$ and dust in the ATAL is similar to the HGP region, reflecting the competing influences of lofting by deep convection, emission quenching (for $\mathrm{CO}$ ) and removal by precipitation washout (for CA and dust). 

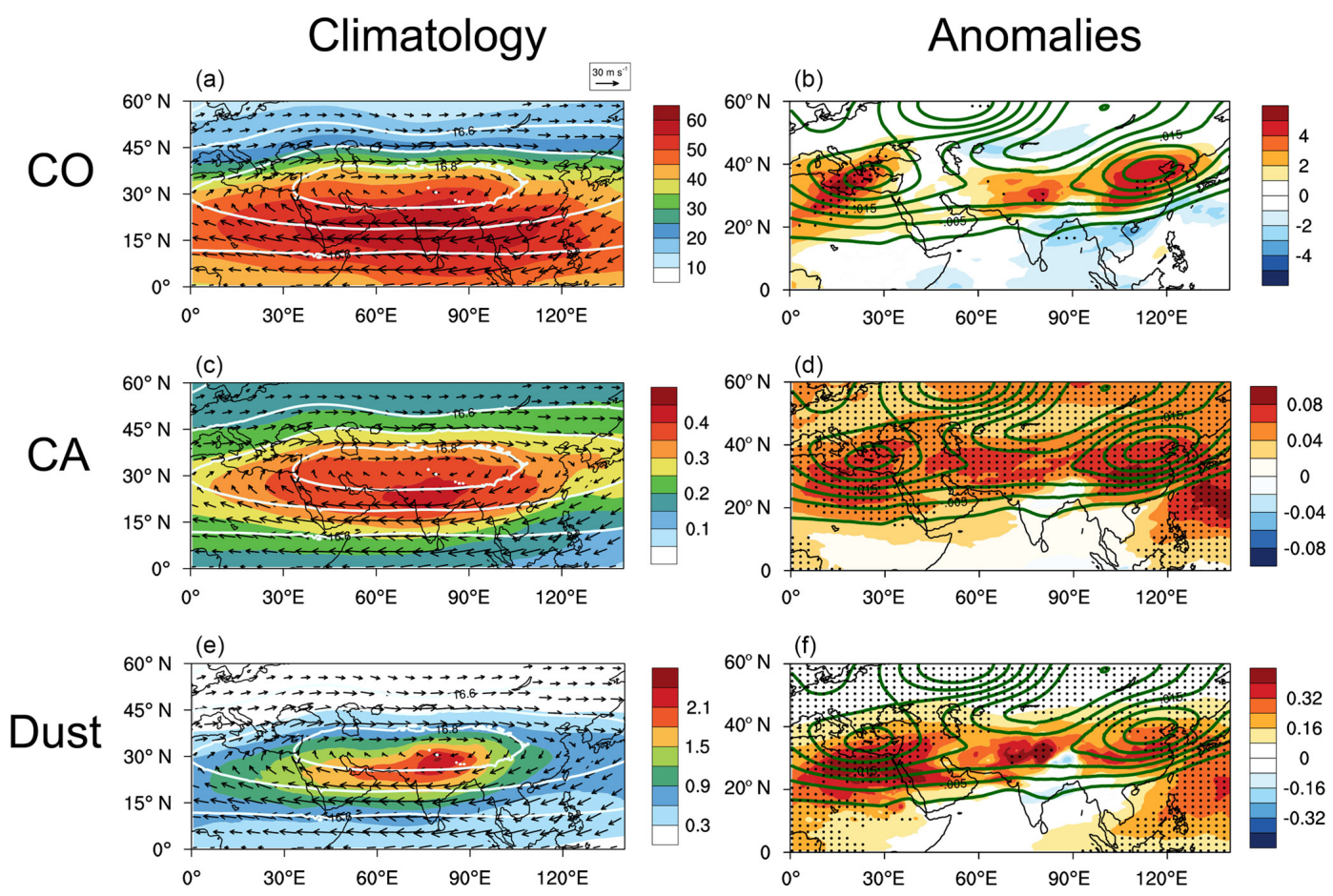

Figure 4. Spatial patterns of chemical gases and aerosol species distributions of (a) CO (ppbv), (c) CA (ppbm) and (e) dust (ppbm) at 108.7 hPa during July-August, superimposed with geopotential height anomalies at $100 \mathrm{hPa}$ (white contours, in $\mathrm{km}$ ) and $108.7 \mathrm{hPa}$ winds (arrows, in $\mathrm{m} \mathrm{s}^{-1}$ ). Panels (b), (d) and (f) are the same as (a), (c) and (e) except that they show anomalous distributions between strong and weak monsoon years ("strong" minus "weak"), superimposed with geopotential height anomalies (green contours) at the same level. Dots represent data points with a significance $>95 \%$.

(a)

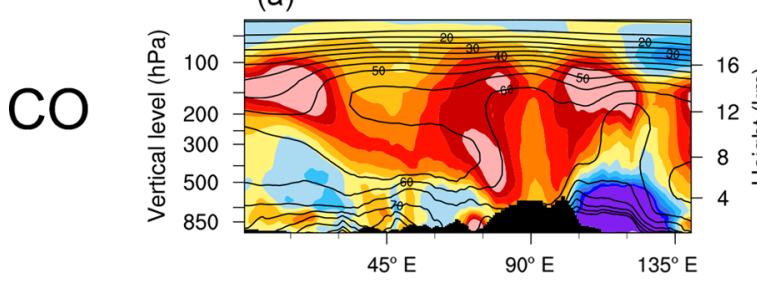

(c)

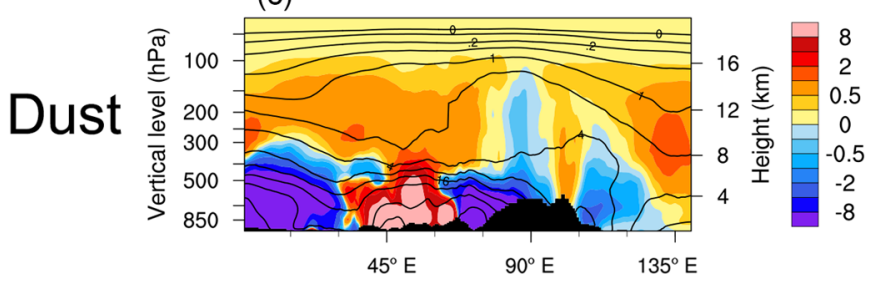

(b)

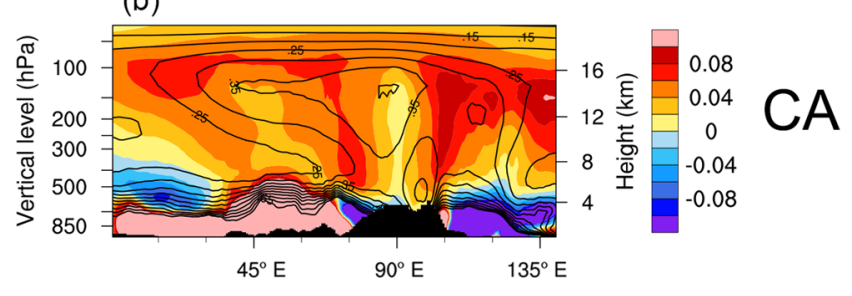

(d)

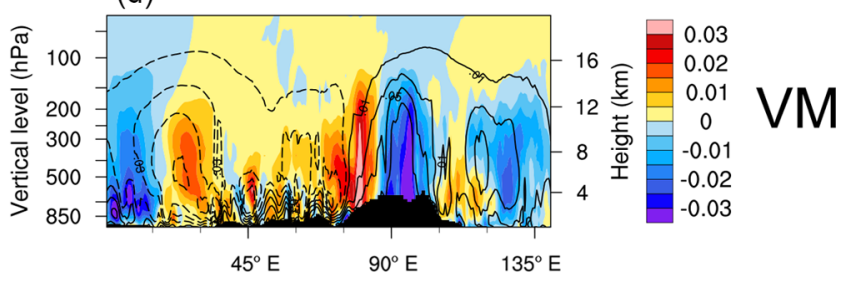

Figure 5. Longitude-height cross sections $\left(0-140^{\circ} \mathrm{E}\right)$ of (a) CO (ppbv), (b) CA (ppbm), (c) dust (ppbm) and (d) vertical motion (Pa s$\left.{ }^{-1}\right)$ anomalies between strong and weak monsoon years ("strong" minus "weak") averaged over the southern portion of the AMA (25-35 N) during July-August, superimposed with the climatological mean of weak monsoon years (black contours). For vertical motions in (d), solid (dashed) contours indicate ascent (descent).

\subsection{Long-term trends}

To depict a long-term change in the ATAL we have computed time series of CO, CA and dust averaged in the $200-100 \mathrm{hPa}$ layer, and over a large domain $\left(60-120^{\circ} \mathrm{E}, 25-35^{\circ} \mathrm{N}\right)$, ap- proximately bounding the AMA. For comparison, a time series representing the strength of the AMA, defined as the difference in zonal winds between northern $\left(30-40^{\circ} \mathrm{N}\right)$ and southern $\left(10-20^{\circ} \mathrm{N}\right)$ flanks of the AMA, has also been constructed (Fig. 7). Clearly, CO and CA in the ATAL show 

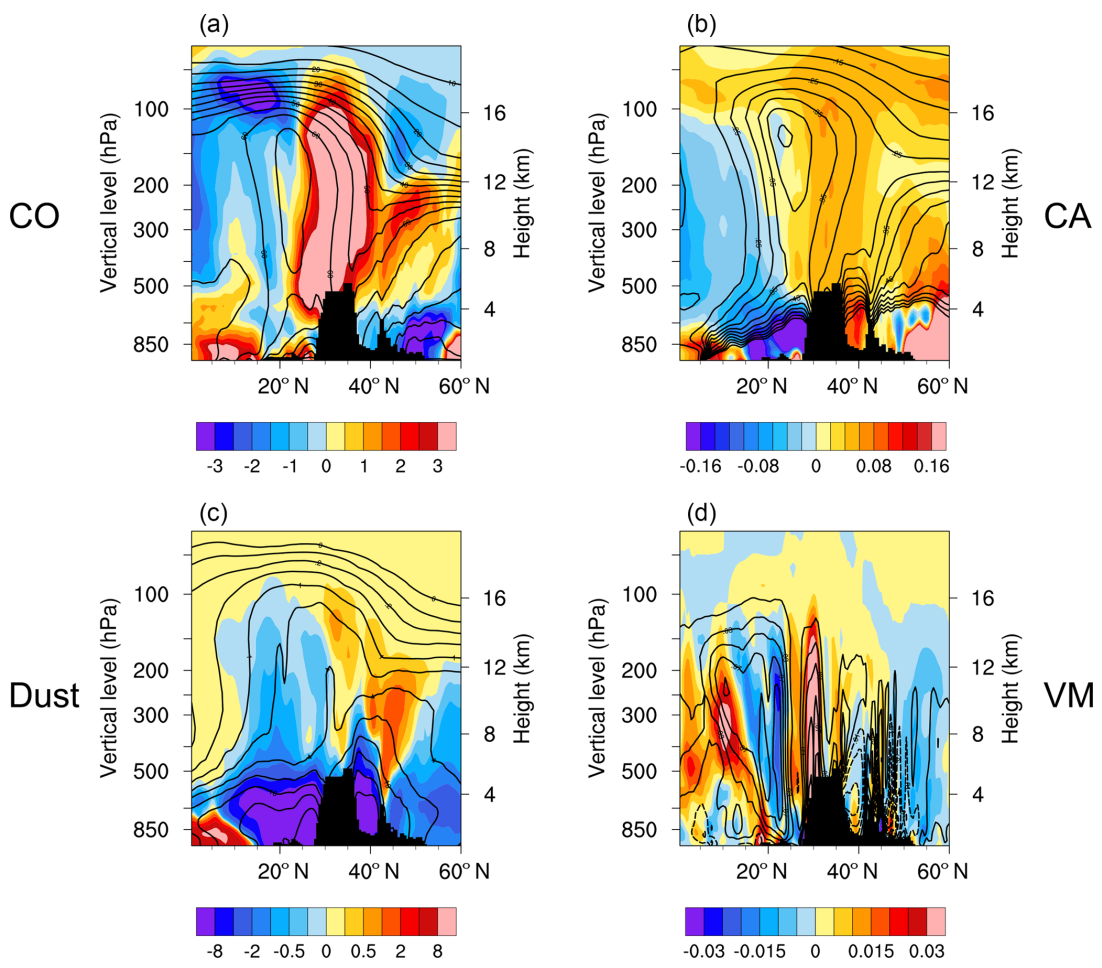

Figure 6. Latitude-height cross sections $\left(0-60^{\circ} \mathrm{N}\right)$ of (a) CO (ppbv), (b) CA (ppbm), (c) dust (ppbm) and (d) vertical motion $\left(\mathrm{Pa} \mathrm{s}{ }^{-1}\right)$ anomalies between strong and weak monsoon years ("strong" minus "weak") averaged over the HGP region (80-85 ${ }^{\circ}$ E) during July-August, superimposed with the climatological mean of weak monsoon years (black contours). For vertical motions in (d), solid (dashed) contours indicate ascent (descent).

significant increasing trends during 2001-2015, at a rate of $+7.8 \%(p$ value $=0.018)$ and $+12.7 \%$ per decade $(p$ value $=0.025)$, respectively. A similar trend of $\mathrm{CO}$ is also seen in the results from MLS observation, and the difference in a certain year can be attributed to bias from observations and the emission inventories used in simulation (Fig. S4). Both the $\mathrm{CO}$ and $\mathrm{CA}$ trends are consistent with a significant ( $p$ value $=0.06)$ trend of AMA strength at a rate of $+6.7 \%$ per decade. Given that the AMA is an essential component of the SASM, this suggests that the trends of increased loading of ATAL CO and CA could be attributed to the strengthening of the SASM during 2001-2015. For dust, the positive trend is weak, with a rate of $1.6 \%$ per decade, and not significant ( $p$ value $=0.875$ ) due to the large interannual variability. The weak ATAL dust trend may be due to the removal of a large fraction of dust particles by wet scavenging in and below raining clouds, outweighing the effects of lofting by deep convection (Chin et al., 2000; Lau et al., 2018). Additionally, the large interannual variability of ATAL dust transport is also likely a reflection of the influence of non-monsoon factors, such as extratropical westerlies that can strongly affect long-range dust transport at high elevations (Sun et al., 2001; Huang et al., 2007).

To better understand the physical processes underpinning the ATAL long-term trend signal, we have constructed the time-mean vertical profiles of ATAL constituents, vertical motions and rainfall along critical east-west cross sections spanning the AMA for the early period (EP; 2001-2006) and later period (LP; 2010-2015), respectively. The longterm change is defined as the difference between the two periods (LP minus EP). Figure 8a-d shows east-west cross sections of long-term changes in $\mathrm{CO}, \mathrm{CA}$, dust and vertical motions respectively, covering the same ASM region as in Fig. 5. During LP, enhanced ascending motions (relative to EP) that reach the ATAL are most pronounced over Pakistan and Northeast India and the HGP region (60-95 E) (Fig. 8d). A cluster of ascending motions are also found over greater SB regions of east Asia $\left(100-130^{\circ} \mathrm{E}\right)$, in connection with the northward migration of the Mei-yu rainbelt (See Fig. 3b). A third region of enhanced ascent is found over northern Africa $\left(15-30^{\circ} \mathrm{E}\right)$. During LP, overall, the CO concentration increases from the surface to the UTLS, with pockets of reduced $\mathrm{CO}$ near the surface due to biomass emission quenching by precipitation (Fig. 8a). Similarly, CA concentration at the UTLS is increased during LP (Fig. 8b), and appears to be connected to surface sources of increased CA over northern Africa and the Middle East and the west Asia region (Fig. S3) via the increased ascending motions over Pakistan and Northeast India and the HGP region $\left(60-90^{\circ}\right.$ E). Strong reduction in $\mathrm{CA}$ from the surface to the mid-troposphere 


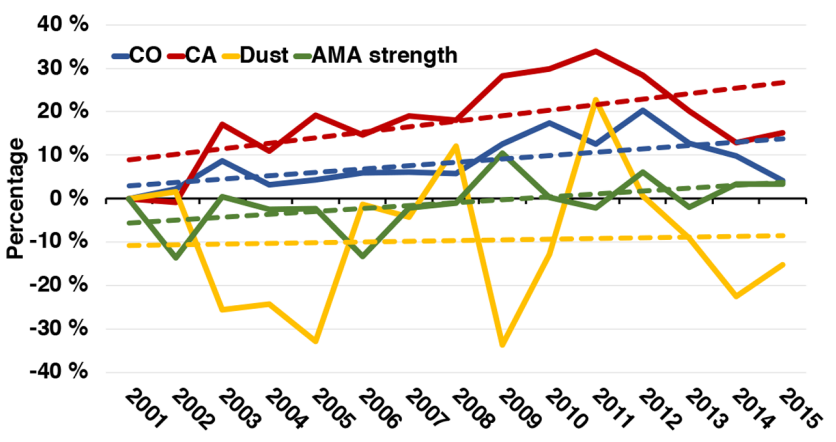

\begin{tabular}{ccc}
\hline & $\begin{array}{c}\text { Increasing rate } \\
\text { (percentage/per decade) }\end{array}$ & $p$ value \\
\hline AMA strength & 6.7 & 0.06 \\
CO & 7.8 & 0.018 \\
CA & 12.7 & 0.025 \\
Dust & 1.6 & 0.875 \\
\hline
\end{tabular}

Figure 7. Time series of CO, CA, dust and AMA strength anomalies (percentage) relative to the first year during 2001-2015. The loading of $\mathrm{CO}, \mathrm{CA}$ and dust is area-averaged over the selected region (that is, $\left.25-35^{\circ} \mathrm{N}, 60-120^{\circ} \mathrm{E}\right)$. The AMA strength is calculated from the percentage difference in zonal wind averaged between 30 and $40^{\circ} \mathrm{N}$ minus zonal wind averaged between 10 and $20^{\circ} \mathrm{N}$ along the sector $60-120^{\circ} \mathrm{E}$. The increasing rate and $p$ value from the significance test for each variable are shown in the table below the graph.

found over east Asia $\left(100-130^{\circ} \mathrm{E}\right)$ is due to the removal by increased precipitation washout. Compared to $\mathrm{CO}$ and $\mathrm{CA}$, the increase in ATAL dust is modest (Fig. 8c), and appears to follow a transport pathway from the surface to the UTLS similar to CA. The increase in surface dust over the Middle East and the west Asia region $\left(40-70^{\circ} \mathrm{E}\right)$ may be related to a robust recent decadal warming trend over the Indian subcontinent and the Middle East (Jin and Wang, 2017). A hotter desert surface is likely to favor a deeper planetary boundary layer, enhanced dry convection and uplifting of dust from the surface (Gamo, 1996; Cuesta et al., 2009). During LP, an overall reduction in dust from the surface to the midtroposphere over monsoon regions is due to removal by increased precipitation washout.

Next, we examine the competing influences of lofting by overshooting convection and precipitation washout in the DSCC stem regions $\left(25-35^{\circ} \mathrm{N}, 65-115^{\circ} \mathrm{E}\right)$, including both the HGP and SB domains. The ATAL trend is found by examining the mean daily variations of monsoon precipitation and vertical profiles of $\mathrm{CO}, \mathrm{CA}$ and dust over the region, during EP and LP, respectively. During LP, monsoon precipitation is enhanced compared to EP from June through August (Fig. 9d, h), consistent with the increased rainfall trend shown in Fig. 1b. CO concentrations from the surface to $200 \mathrm{hPa}$ in LP are higher than in EP during the pre-monsoon period in May-mid-June (Fig. 9a, e), reflecting a hotter land surface and enhanced dry convection over the region before monsoon onset. The onset of the monsoon, as characterized by an abrupt rise in $\mathrm{CO}$ (region shaded by light yellow in Fig. 9a, e) to above $200 \mathrm{hPa}$ reaching the ATAL, occurs earlier in LP (around 16 June) compared to EP (around 1 July). Thereafter, CO remains higher in LP, through the end of the monsoon season, maintaining a longer residence time in the ATAL, via the cumulative effect (multiyear mean) of lofting by deep convection. From the surface to the lower troposphere, $\mathrm{CO}$ concentration declines faster in LP, due to the quenching of emission by heavier monsoon rain. Likewise, for CA, features such as the earlier onset, the increased ATAL concentration (above $200 \mathrm{hPa}$ ) and the longer residence time during LP are also pronounced (Fig. 9b, f). The competing influences of convective lofting and wet removal can be seen in the more episodic increase in ATAL loading in both EP and LP, more so in the latter. During LP, the more efficient lofting of CA into the ATAL from the mid-troposphere during early July and late August coincides approximately with the time of maximum precipitation, when deeper and more overshooting convection tends to occur (Fig. 9f). During May in LP, a strong increase in CA from the surface to $200 \mathrm{hPa}$ is noted. This could be related to a warming trend of the land surface over northern India and the desert regions to the west (Jin and Wang, 2017). A warmer and drier land surface before monsoon onset is likely to favor increased biomass burning emissions (van der Werf et al., 2006) (Fig. S5). In contrast to $\mathrm{CO}$ and $\mathrm{CA}$, dust concentration in the ATAL varies little from EP years to LP, with a slight signal of increased convective lofting during mid-July to mid-August in LP. This is consistent with the weak positive, but statistically insignificant, dust trend shown in Fig. 7. A notable signal is the increase in dust loading from the surface to $300 \mathrm{hPa}$ during May in LP compared to EP and a rapid decline due to removal by washout during June-August. A similar analysis has also been carried out separately for the HGP and SB regions. Results show that while both regions exhibit similar characteristic features regarding convective lofting and washout, the signal over the HGP is more pronounced than that over the SB region (Figs. S6 and S7). This may be because the Mei-yu rainfall system affecting the SB region possesses more transient and migratory features compared to the more landlocked convection over the HGP region (Ding and Chan, 2005; Lau and Weng, 2001).

\section{Summary}

In this study, we have investigated the roles of monsoon physical processes in the interannual variability and longterm change of ATAL gaseous and aerosol species, i.e., $\mathrm{CO}$, carbonaceous aerosol (CA) and dust using 15 years (20012015) of NASA MERRA-2 reanalysis data. A monsoon index based on areal mean rainfall over the South Asia summer monsoon (SASM) region shows strong interannual variability and a robust long-term trend. Composite analyses were carried out comparing strong monsoon years (SM) vs. weak 
(a)

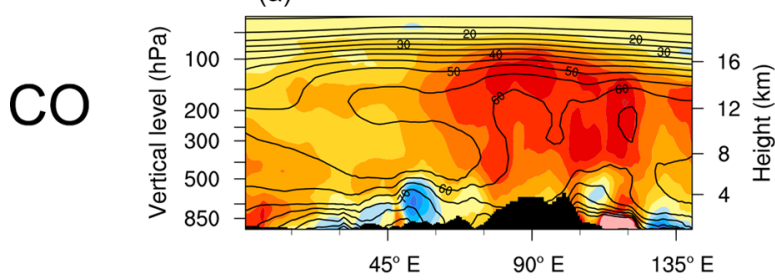

(c)

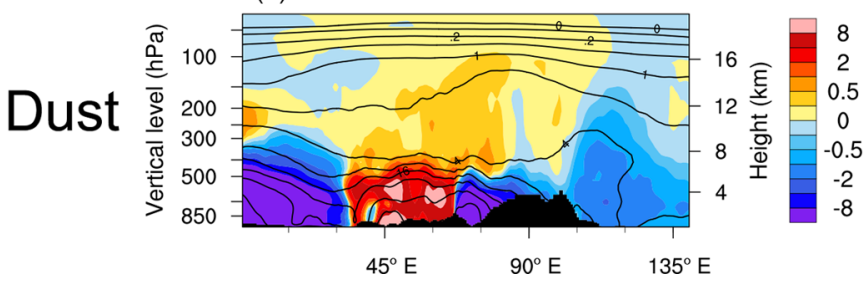

(b)

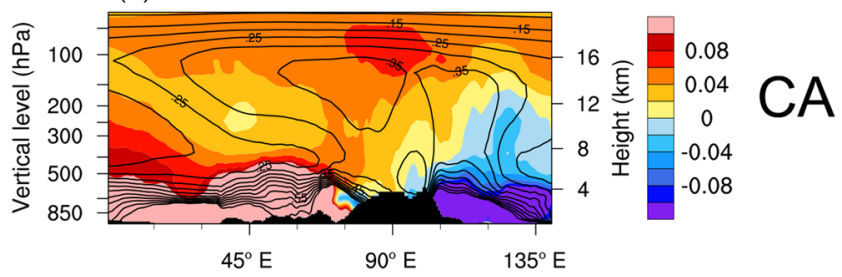

(d)

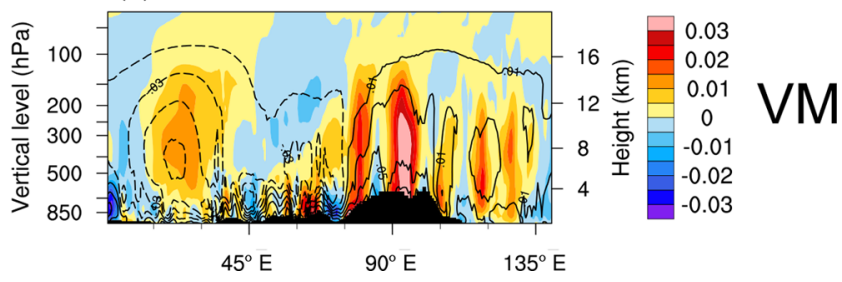

Figure 8. Longitude-height cross sections $\left(0-140^{\circ} \mathrm{E}\right)$ of (a) CO (ppbv), (b) CA (ppbm), (c) dust (ppbm) and (d) vertical motion (Pa s $\left.{ }^{-1}\right)$ anomalies between late part years and early part years ("late" minus "early") averaged over the southern portion of the AMA (25-35 N) during July-August, superimposed with the climatological mean of early part years (black contours). For vertical motions in (d), solid (dashed) contours indicate ascent (descent).
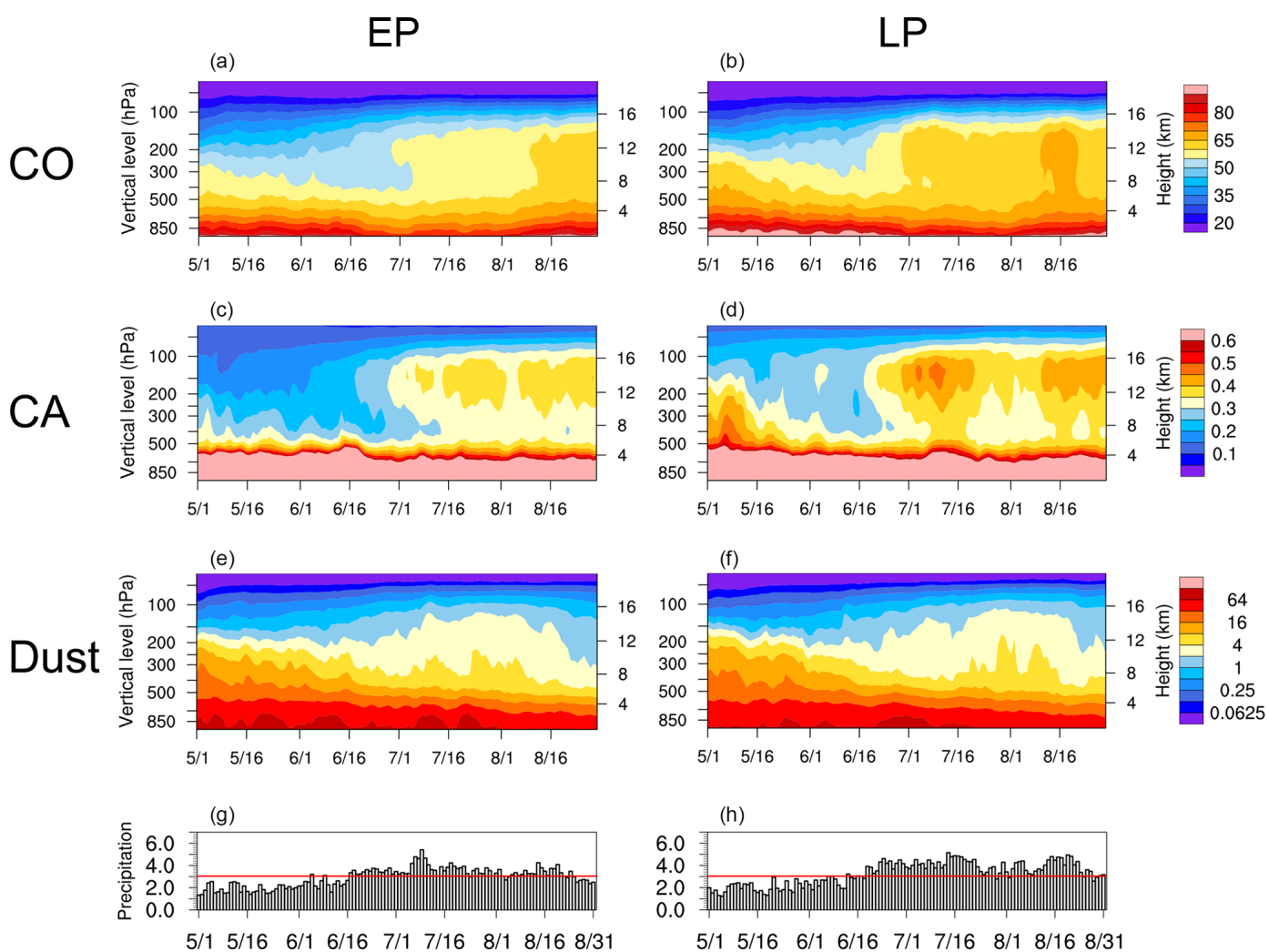

Figure 9. Time-height cross sections showing daily variations in (a) CO (ppbv), (c) CA (ppbm), (e) dust (ppbm) and (g) precipitation $\left(\mathrm{mm} \mathrm{day}^{-1}\right)$ during early part years over the DSCC stem regions $\left(25-35^{\circ} \mathrm{N}, 65-115^{\circ} \mathrm{E}\right)$. Panels (b), (d), (f) and (h) are the same as (a), (c), (e) and (g) but for late part years. Red lines in (g) and (h) show the reference value of precipitation intensity $\left(3 \mathrm{~mm} \mathrm{day}^{-1}\right)$.

monsoon years (WM) based on the detrended data. Regression trend and composite analyses were carried out using the full data. During SM, the Asian monsoon anticyclone (AMA) is expanded, and shifted poleward relative to weak monsoon years, in conjunction with enhanced heating over the upper troposphere above the TP, cooling in the lower stratosphere and a rise of the tropopause height, relative to WM. During SM, more ambient $\mathrm{CO}, \mathrm{CA}$ and dust enter the ATAL 
from preferred pathways over the foothills of the HimalayasGangetic Plain (HGP) and the Sichuan Basin (SB). Upon entering the ATAL, these constituents are advected by the anomalous AMA circulation, which appears to be a component of a planetary-scale Rossby wave train connecting the tropics and extratropics. As a result, enhanced loading of $\mathrm{CO}$, $\mathrm{CA}$ and dust is found in an elongated accumulation zone on the southern flank of the extended AMA. During SM, enhanced UTLS transport of CO and CA to the ATAL can be attributed to lofting by deep convection over the HGP and $\mathrm{SB}$ stem regions. While $\mathrm{CO}$ and $\mathrm{CA}$, from the surface to the mid-troposphere in the stem regions, are reduced during the peak monsoon season due to enhanced wet scavenging, more ambient $\mathrm{CO}$ and $\mathrm{CA}$ in the middle and upper troposphere continued to be transported into the ATAL due to increased overshooting convection. While stronger low-level westerlies transport more dust to the Indian subcontinent during SM, stronger precipitation washout suppresses dust loading near the surface in both the HGP and the SB stem regions. Dust over west Asia and the Middle East and the subtropical area in northwestern China contributes mostly to the dust enhancement in the UTLS.

We found robust positive significant decadal trends in $\mathrm{CO}$ and CA, as well as a weak positive but insignificant trend in dust in the ATAL. Overall, these trends are associated with an earlier onset of stronger overshooting convection over the HGP and SB regions, transporting ambient $\mathrm{CO}, \mathrm{CA}$ and dust into the ATAL in conjunction with a strengthening of the Asian summer monsoon during 2001-2015. The increase in ATAL constituents occurs, even though there is reduction in surface $\mathrm{CO}$ due to emission quenching and strong reduction in $\mathrm{CA}$ and dust due to increased precipitation washout in Asian monsoon regions during this period.

It should be noted that there are limitations in using the MERRA-2 aerosol species concentrations for interannual variability and long-term trend analysis. The MERRA-2 system adjusts the model simulation according to the total AOD retrieved from satellite measurements during assimilation, but there is no speciated aerosol information from satellite data to allow for changes of aerosol composition, which are simulated by the widely used chemical model of GOGART (Chin, 2000, 2002, 2016; Kim, 2017). As a result, all modelsimulated aerosol species had to be adjusted by the same factor, which can introduce artifacts for the increase or decrease of individual aerosol mass or AOD (Randles et al., 2017). To test if the interannual variability or long-term trends of individual aerosol species inferred from MERRA-2 might be contaminated by any nonphysical corrections of individual aerosol species during the assimilation process, we have taken a look at the increments for CA and dust from the MERRA-2 dataset. Results show that in our research domain, the assimilation increments for CA and dust aerosols are very small. In most cases, it is nearly zero and the ratio of the rest increment to the values of the model mean signal is less than
$1 \%$. Therefore, the model aerosol physics are likely to be reasonable.

As a caveat, we note that while we have found overall significant relationships connecting interannual variability and long-term trends in ATAL constituent transport processes and monsoon strength, this study leaves open the question of how changes in anthropogenic emissions may affect the relationships. This is because the MERRA-2 emission inventories of aerosols species have not been updated since the mid-2000s (Randles et al., 2017). Moreover, recent modeling studies have suggested that the mixing state and aging processes can largely change the aerosol lifetime during simulation, and consequently affect the amount of aerosols lifted to UTLS, and some optical measurements further support the result that dust aerosol can be coated by anthropogenic aerosols over east Asia and then significantly enhance absorbing ability (Wang et al., 2018; Tian et al., 2018). Nonetheless, our findings provide a working hypothesis that warrants further investigations using both modeling and observational studies. Long-term top-down satellite observations and bottomup field observations including updated emission inventories, as well as intercomparison among climate models with stateof-the-art representation of aerosol physics and chemistry, will be needed to test our hypothesis.

Data availability. MERRA-2 reanalysis data are available at https://disc.sci.gsfc.nasa.gov/daac-bin/FTPSubset2.pl (Gelaro et al., 2017). The datasets processed and/or analyzed during this study are available from the corresponding author upon reasonable request.

Supplement. The supplement related to this article is available online at: https://doi.org/10.5194/acp-19-1901-2019-supplement.

Author contributions. CY performed the data analysis, WL designed research, WL and ZL provided advice from the analysis perspective and CY, WL, ZL and MC wrote the manuscript.

Competing interests. The authors declare that they have no conflict of interest.

Acknowledgements. This study is partially supported by the NASA Modeling and Analysis Program and the National Science Foundation (AGS1837811). Cheng Yuan also acknowledges support from the China Scholarship Council (201506190077).

Edited by: Xiaohong Liu

Reviewed by: four anonymous referees 


\section{References}

Babu, S. S., Moorthy, K. K., Manchanda, R. K., Sinha, P. R., Satheesh, S. K., Vajja, D. P., Srinivasan, S., and Kumar, V. H. A.: Free tropospheric black carbon aerosol measurements using high altitude balloon: Do BC layers build "their own homes" up in the atmosphere?, Geophys. Res. Lett., 38, L08803, https://doi.org/10.1029/2011GL046654, 2011.

Bergman, J. W., Fierli, F., Jensen, E. J., Honomichl, S., and Pan, L. L.: Boundary layer sources for the Asian anticyclone: Regional contributions to a vertical conduit, J. Geophys. Res.-Atmos., 118, 2560-2575, https://doi.org/10.1002/jgrd.50142, 2013.

Bergman, J. W., Pfister, L., and Yang, Q.: Identifying robust transport features of the upper tropical troposphere, J. Geophys. Res.-Atmos., 120, 6758-6776, https://doi.org/10.1002/2015JD023523, 2015.

Bourassa, A. E., Robock, A., Randel, W. J., Deshler, T., Rieger, L. A., Lloyd, N. D., Llewellyn, E. J., and Degenstein, D. A.: Large Volcanic Aerosol Load in the Stratosphere Linked to Asian Monsoon Transport, Science, 337, 78-81, https://doi.org/10.1126/science.1219371, 2012.

Chin, M., Rood, R. B., Lin, S. J., Müller, J. F., and Thompson, A. M.: Atmospheric sulfur cycle simulated in the global model GOCART: Model description and global properties, J. Geophys. Res.-Atmos., 105, 24671-24687, https://doi.org/10.1029/2000JD900384, 2000.

Chin, M., Ginoux, P., Kinne, S., Torres, O., Holben, B. N., Duncan, B. N., Martin, R. V., Logan, J. A., Higurashi, A., and Nakajima, T.: Tropospheric Aerosol Optical Thickness from the GOCART Model and Comparisons with Satellite and Sun Photometer Measurements, J. Atmos. Sci., 59, 461-483, https://doi.org/10.1175/15200469(2002)059<0461:taotft>2.0.co;2, 2002.

Chin, M., Diehl, T., Bian, H., and Kucsera, T.: Aerosols in the Atmosphere: Sources, Transport, and Multi-decadal Trends, in: Air Pollution Modeling and its Application XXIV, Cham, 3-10, 2016.

Cuesta, J., Marsham, J. H., Parker, D. J., and Flamant, C.: Dynamical mechanisms controlling the vertical redistribution of dust and the thermodynamic structure of the West Saharan atmospheric boundary layer during summer, Atmos. Sci. Lett., 10, 34-42, https://doi.org/10.1002/asl.207, 2009.

Darmenov, A. and da Silva, A.: The quick fire emissions dataset (QFED)-documentation of versions 2.1, 2.2 and 2.4, NASA Technical Report Series on Global Modeling and Data Assimilation, NASA TM-2013-104606, 32, 183, 2013.

Diehl, T., Heil, A., Chin, M., Pan, X., Streets, D., Schultz, M., and Kinne, S.: Anthropogenic, biomass burning, and volcanic emissions of black carbon, organic carbon, and $\mathrm{SO}_{2}$ from 1980 to 2010 for hindcast model experiments, Atmos. Chem. Phys. Discuss., 12, 24895-24954, https://doi.org/10.5194/acpd-12-248952012, 2012.

Ding, Y. and Chan, J. C. L.: The East Asian summer monsoon: an overview, Meteorol. Atmos. Phys., 89, 117-142, https://doi.org/10.1007/s00703-005-0125-z, 2005.

Fadnavis, S., Semeniuk, K., Pozzoli, L., Schultz, M. G., Ghude, S. D., Das, S., and Kakatkar, R.: Transport of aerosols into the UTLS and their impact on the Asian monsoon region as seen in a global model simulation, Atmos. Chem. Phys., 13, 8771-8786, https://doi.org/10.5194/acp-13-8771-2013, 2013.
Gamo, M.: Thickness of the dry convection and large-scale subsidence above deserts, Bound.-Lay. Meteorol., 79, 265-278, https://doi.org/10.1007/bf00119441, 1996.

Garny, H. and Randel, W. J.: Transport pathways from the Asian monsoon anticyclone to the stratosphere, Atmos. Chem. Phys., 16, 2703-2718, https://doi.org/10.5194/acp-16-27032016, 2016.

Gautam, R., Hsu, N. C., Lau, K.-M., and Kafatos, M.: Aerosol and rainfall variability over the Indian monsoon region: distributions, trends and coupling, Ann. Geophys., 27, 3691-3703, https://doi.org/10.5194/angeo-27-3691-2009, 2009a.

Gautam, R., Liu, Z., Singh, R. P., and Hsu, N. C.: Two contrasting dust-dominant periods over India observed from MODIS and CALIPSO data, Geophys. Res. Lett., 36, L06813, https://doi.org/10.1029/2008GL036967, 2009b.

Gelaro, R., McCarty, W., Suárez, M. J., Todling, R., Molod, A., Takacs, L., Randles, C. A., Darmenov, A., Bosilovich, M. G., Reichle, R., Wargan, K., Coy, L., Cullather, R., Draper, C., Akella, S., Buchard, V., Conaty, A., Da Silva, A. M., Gu, W., Kim, G. K., Koster, R., Lucchesi, R., Merkova, D., Nielsen, J. E., Partyka, G., Pawson, S., Putman, W., Rienecker, M., Schubert, S. D., Sienkiewicz, M., and Zhao, B.: The Modern-Era Retrospective Analysis for Research and Applications, Version 2 (MERRA2), J. Climate, 30, 5419-5454, https://doi.org/10.1175/jcli-d-160758.1, 2017 (data available at: https://disc.sci.gsfc.nasa.gov/ daac-bin/FTPSubset2.pl, last access: 14 January 2019).

Gettelman, A., Kinnison, D. E., Dunkerton, T. J., and Brasseur, G. P.: Impact of monsoon circulations on the upper troposphere and lower stratosphere, J. Geophys. Res.-Atmos., 109, D22101, https://doi.org/10.1029/2004JD004878, 2004.

Houze, R. A., Wilton, D. C., and Smull, B. F.: Monsoon convection in the Himalayan region as seen by the TRMM Precipitation Radar, Q. J. Roy. Meteor. Soc., 133, 1389-1411, https://doi.org/10.1002/qj.106, 2007.

Huang, J., Minnis, P., Yi, Y., Tang, Q., Wang, X., Hu, Y., Liu, Z., Ayers, K., Trepte, C., and Winker, D.: Summer dust aerosols detected from CALIPSO over the Tibetan Plateau, Geophys. Res. Lett., 34, L18805, https://doi.org/10.1029/2007GL029938, 2007.

Huang, R. and Sun, F.: Impacts of the Tropical Western Pacific on the East Asian Summer Monsoon, J. Meteorol. Soc. Jpn., 70, 243-256, https://doi.org/10.2151/jmsj1965.70.1B_243, 1992.

Jin, Q. and Wang, C.: A revival of Indian summer monsoon rainfall since 2002, Nat. Clim. Change, 7, 587-594, https://doi.org/10.1038/nclimate3348, 2017.

Kim, D., Chin, M., Kemp, E. M., Tao, Z., Peters-Lidard, C. D., and Ginoux, P.: Development of high-resolution dynamic dust source function - A case study with a strong dust storm in a regional model, Atmos. Environ., 159, 11-25, https://doi.org/10.1016/j.atmosenv.2017.03.045, 2017.

Kim, M. K., Lau, W. K. M., Kim, K. M., Sang, J., Kim, Y. H., and Lee, W. S.: Amplification of ENSO effects on Indian summer monsoon by absorbing aerosols, Clim. Dynam., 46, 2657-2671, https://doi.org/10.1007/s00382-015-2722-y, 2016.

Kremser, S., Thomason, L. W., von Hobe, M., Hermann, M., Deshler, T., Timmreck, C., Toohey, M., Stenke, A., Schwarz, J. P., Weigel, R., Fueglistaler, S., Prata, F. J., Vernier, J.-P., Schlager, H., Barnes, J. E., Antuña-Marrero, J.-C., Fairlie, D., Palm, M., Mahieu, E., Notholt, J., Rex, M., Bingen, C., Vanhellemont, F., Bourassa, A., Plane, J. M. C., Klocke, D., Carn, S. A., Clarisse, 
L., Trickl, T., Neely, R., James, A. D., Rieger, L., Wilson, J. C., and Meland, B.: Stratospheric aerosol - Observations, processes, and impact on climate, Rev. Geophys., 54, 278-335, https://doi.org/10.1002/2015RG000511, 2016.

Kulkarni, P., Ramachandran, S., Bhavani Kumar, Y., Narayana Rao, D., and Krishnaiah, M.: Features of upper troposphere and lower stratosphere aerosols observed by lidar over Gadanki, a tropical Indian station, J. Geophys. Res.-Atmos., 113, D17207, https://doi.org/10.1029/2007JD009411, 2008.

Lau, K. M., Kim, K. M., and Yang, S.: Dynamical and Boundary Forcing Characteristics of Regional Components of the Asian Summer Monsoon, J. Climate, $13, \quad 2461-2482$, https://doi.org/10.1175/15200442(2000)013<2461:dabfco>2.0.co;2, 2000.

Lau, K. M. and Weng, H.: Coherent Modes of Global SST and Summer Rainfall over China: An Assessment of the Regional Impacts of the 1997-98 El Niño, J. Climate, 14, 1294-1308, https://doi.org/10.1175/15200442(2001)014<1294:cmogsa>2.0.co;2, 2001.

Lau, K. M. and Kim, K. M.: Observational relationships between aerosol and Asian monsoon rainfall, and circulation, Geophys. Res. Lett., 33, L21810, https://doi.org/10.1029/2006GL027546, 2006.

Lau, K. M., Kim, M. K., and Kim, K. M.: Asian summer monsoon anomalies induced by aerosol direct forcing: the role of the Tibetan Plateau, Clim. Dynam., 26, 855-864, https://doi.org/10.1007/s00382-006-0114-z, 2006.

Lau, K. M., Tsay, S. C., Hsu, C., Chin, M., Ramanathan, V., Wu, G.-X., Li, Z., Sikka, R., Holben, B., Lu, D., Chen, H., Tartari, G., Koudelova, P., Ma, Y., Huang, J., Taniguchi, K., and Zhang, R.: The Joint Aerosol-Monsoon Experiment: A New Challenge for Monsoon Climate Research, B. Am. Meteorol. Soc., 89, 369383, https://doi.org/10.1175/bams-89-3-369, 2008.

Lau, W.: Atmospheric science: Desert dust and monsoon rain, Nat. Geosci., 7, 255-256, https://doi.org/10.1038/ngeo2115, 2014.

Lau, W. K. M.: The aerosol-monsoon climate system of Asia: A new paradigm, J. Meteorol. Res., 30, 1-11, https://doi.org/10.1007/s13351-015-5999-1, 2016.

Lau, W. K. M. and Kim, K. M.: The 2010 Pakistan Flood and Russian Heat Wave: Teleconnection of Hydrometeorological Extremes, J. Hydrometeorol., 13, 392-403, https://doi.org/10.1175/jhm-d-11-016.1, 2012.

Lau, W. K. M., Yuan, C., and Li, Z.: Origin, Maintenance and Variability of the Asian Tropopause Aerosol Layer (ATAL): The Roles of Monsoon Dynamics, Sci. Rep., 8, 3960-3973, https://doi.org/10.1038/s41598-018-22267-z, 2018.

Lelieveld, J., Bourtsoukidis, E., Brühl, C., Fischer, H., Fuchs, H., Harder, H., Hofzumahaus, A., Holland, F., Marno, D., Neumaier, M., Pozzer, A., Schlager, H., Williams, J., Zahn, A., and Ziereis, H.: The South Asian monsoon - Pollution pump and purifier, Science, 270-273, https://doi.org/10.1126/science.aar2501, 2018.

Li, Q., Jiang, J. H., Wu, D. L., Read, W. G., Livesey, N. J., Waters, J. W., Zhang, Y., Wang, B., Filipiak, M. J., Davis, C. P., Turquety, S., Wu, S., Park, R. J., Yantosca, R. M., and Jacob, D. J.: Convective outflow of South Asian pollution: A global CTM simulation compared with EOS MLS observations, Geophys. Res. Lett., 32, L14826, https://doi.org/10.1029/2005GL022762, 2005.

Medina, S., Houze, R. A., Kumar, A., and Niyogi, D.: Summer monsoon convection in the Himalayan region: terrain and land cover effects, Q. J. Roy. Meteor. Soc., 136, 593-616, https://doi.org/10.1002/qj.601, 2010.

Meehl, G. A., Arblaster, J. M., and Collins, W. D.: Effects of Black Carbon Aerosols on the Indian Monsoon, J. Climate, 21, 28692882, https://doi.org/10.1175/2007jcli1777.1, 2008.

Molod, A., Takacs, L., Suarez, M., and Bacmeister, J.: Development of the GEOS-5 atmospheric general circulation model: evolution from MERRA to MERRA2, Geosci. Model Dev., 8, 1339-1356, https://doi.org/10.5194/gmd-8-1339-2015, 2015.

Neely, R. R., Yu, P., Rosenlof, K. H., Toon, O. B., Daniel, J. S., Solomon, S., and Miller, H. L.: The contribution of anthropogenic $\mathrm{SO}_{2}$ emissions to the Asian tropopause aerosol layer, J. Geophys. Res.-Atmos., 119, 1571-1579, https://doi.org/10.1002/2013JD020578, 2014.

Pan, L. L., Honomichl, S. B., Kinnison, D. E., Abalos, M., Randel, W. J., Bergman, J. W., and Bian, J.: Transport of chemical tracers from the boundary layer to stratosphere associated with the dynamics of the Asian summer monsoon, J. Geophys. Res.-Atmos., 121, 14159-14174, https://doi.org/10.1002/2016JD025616, 2016.

Park, M., Randel, W. J., Gettelman, A., Massie, S. T., and Jiang, J. H.: Transport above the Asian summer monsoon anticyclone inferred from Aura Microwave Limb Sounder tracers, J. Geophys. Res.-Atmos., 112, D16309, https://doi.org/10.1029/2006JD008294, 2007.

Park, M., Randel, W. J., Emmons, L. K., and Livesey, N. J.: Transport pathways of carbon monoxide in the Asian summer monsoon diagnosed from Model of Ozone and Related Tracers (MOZART), J. Geophys. Res.-Atmos., 114, D08303, https://doi.org/10.1029/2008JD010621, 2009.

Ploeger, F., Gottschling, C., Griessbach, S., Grooß, J.-U., Guenther, G., Konopka, P., Müller, R., Riese, M., Stroh, F., Tao, M., Ungermann, J., Vogel, B., and von Hobe, M.: A potential vorticitybased determination of the transport barrier in the Asian summer monsoon anticyclone, Atmos. Chem. Phys., 15, 13145-13159, https://doi.org/10.5194/acp-15-13145-2015, 2015.

Qu, W., Wang, J., Zhang, X., Sheng, L., and Wang, W.: Opposite seasonality of the aerosol optical depth and the surface particulate matter concentration over the north China Plain, Atmos. Environ., 127, 90-99, https://doi.org/10.1016/j.atmosenv.2015.11.061, 2016.

Randel, W. J. and Park, M.: Deep convective influence on the Asian summer monsoon anticyclone and associated tracer variability observed with Atmospheric Infrared Sounder (AIRS), J. Geophys. Res.-Atmos., 111, D12314, https://doi.org/10.1029/2005JD006490, 2006.

Randel, W. J., Park, M., Emmons, L., Kinnison, D., Bernath, P., Walker, K. A., Boone, C., and Pumphrey, H.: Asian Monsoon Transport of Pollution to the Stratosphere, Science, 328, 611613, https://doi.org/10.1126/science.1182274, 2010.

Randles, C. A., Silva, A. M. d., Buchard, V., Colarco, P. R., Darmenov, A., Govindaraju, R., Smirnov, A., Holben, B., Ferrare, R., Hair, J., Shinozuka, Y., and Flynn, C. J.: The MERRA-2 Aerosol Reanalysis, 1980 Onward. Part I: System Description and Data Assimilation Evaluation, J. Climate, 30, 6823-6850, https://doi.org/10.1175/jcli-d-16-0609.1, 2017.

Reichle, R. H., Liu, Q., Koster, R. D., Draper, C. S., Mahanama, S. P. P., and Partyka, G. S.: Land Surface Precipitation in MERRA- 
2, J. Climate, 30, 1643-1664, https://doi.org/10.1175/jcli-d-16$0570.1,2017$.

Rodwell, M. J. and Hoskins, B. J.: Monsoons and the dynamics of deserts, Q. J. Roy. Meteor. Soc., 122, 1385-1404, https://doi.org/10.1002/qj.49712253408, 1996.

Sanap, S. and Pandithurai, G.: Inter-annual variability of aerosols and its relationship with regional climate over Indian subcontinent, Int. J. Climatol., 35, 1041-1053, 2015.

Santee, M. L., Manney, G. L., Livesey, N. J., Schwartz, M. J., Neu, J. L., and Read, W. G.: A comprehensive overview of the climatological composition of the Asian summer monsoon anticyclone based on 10 years of Aura Microwave Limb Sounder measurements, J. Geophys. Res.-Atmos., 122, 54915514, https://doi.org/10.1002/2016JD026408, 2017.

Sun, J., Zhang, M., and Liu, T.: Spatial and temporal characteristics of dust storms in China and its surrounding regions, 1960-1999: Relations to source area and climate, J. Geophys. Res.-Atmos., 106, 10325-10333, https://doi.org/10.1029/2000JD900665, 2001.

Tao, S., Zhang, S., and Zhang, Q.: An observational study of the behavior of the subtropical high over the West Pacific Ocean, Acta Meteorol. Sin., 59, 747-758, 2001.

Thomason, L. W. and Vernier, J.-P.: Improved SAGE II cloud/aerosol categorization and observations of the Asian tropopause aerosol layer: 1989-2005, Atmos. Chem. Phys., 13, 4605-4616, https://doi.org/10.5194/acp-13-4605-2013, 2013.

Tobo, Y., Iwasaka, Y., Shi, G. Y., Kim, Y. S., Ohashi, T., Tamura, K., and Zhang, D.: Balloon-borne observations of high aerosol concentrations near the summertime tropopause over the Tibetan Plateau, Atmos. Res., 84, 233-241, https://doi.org/10.1016/j.atmosres.2006.08.003, 2007.

Tian, P., Zhang, L., Ma, J., Tang, K., Xu, L., Wang, Y., Cao, X., Liang, J., Ji, Y., Jiang, J. H., Yung, Y. L., and Zhang, R.: Radiative absorption enhancement of dust mixed with anthropogenic pollution over East Asia, Atmos. Chem. Phys., 18, 7815-7825, https://doi.org/10.5194/acp-18-7815-2018, 2018.

van der Werf, G. R., Randerson, J. T., Giglio, L., Collatz, G. J., Kasibhatla, P. S., and Arellano Jr., A. F.: Interannual variability in global biomass burning emissions from 1997 to 2004, Atmos. Chem. Phys., 6, 3423-3441, https://doi.org/10.5194/acp-6-34232006, 2006.

Vernier, J. P., Thomason, L. W., and Kar, J.: CALIPSO detection of an Asian tropopause aerosol layer, Geophys. Res. Lett., 38, L07804, https://doi.org/10.1029/2010GL046614, 2011.

Vernier, J. P., Fairlie, T. D., Natarajan, M., Wienhold, F. G., Bian, J., Martinsson, B. G., Crumeyrolle, S., Thomason, L. W., and Bedka, K. M.: Increase in upper tropospheric and lower stratospheric aerosol levels and its potential connection with Asian pollution, J. Geophys. Res.-Atmos., 120, 1608-1619, https://doi.org/10.1002/2014JD022372, 2015.

Vernier, J. P., Fairlie, T. D., Deshler, T., Ratnam, M. V., Gadhavi, H., Kumar, S., Natarajan, M., Pandit, A. K., Raj, S. T. A., Kumar, A. H., Jayaraman, A., Singh, A. K., Rastogi, N., Sinha, P. R., Kumar, S., Tiwari, S., Wegner, T., Baker, N., Vignelles, D., Stenchikov, G., Shevchenko, I., Smith, J., Bedka, K., Kesarkar, A., Singh, V., Bhate, J., Ravikiran, V., Rao, M. D., Ravindrababu, S., Patel, A., Vernier, H., Wienhold, F. G., Liu, H., Knepp, T., Thomason, L., Crawford, J., Ziemba, L., Moore, J., Crumeyrolle, S., Williamson, M., Berthet, G., Jégou, F., and Renard, J.
B.: BATAL: The Balloon measurement campaigns of the Asian Tropopause Aerosol Layer, B. Am. Meteorol. Soc., 99, 955-973, https://doi.org/10.1175/bams-d-17-0014.1, 2017.

Vinoj, V., Rasch, P. J., Wang, H., Yoon, J.-H., Ma, P.-L., Landu, K., and Singh, B.: Short-term modulation of Indian summer monsoon rainfall by West Asian dust, Nat. Geosci., 7, 308-313, https://doi.org/10.1038/ngeo2107, 2014.

Vogel, B., Günther, G., Müller, R., Grooß, J.-U., and Riese, M.: Impact of different Asian source regions on the composition of the Asian monsoon anticyclone and of the extratropical lowermost stratosphere, Atmos. Chem. Phys., 15, 13699-13716, https://doi.org/10.5194/acp-15-13699-2015, 2015.

Wang, B.: The Asian Monsoon, edited by: Wang, B., Springer Science \& Business Media, Chichester, UK, 2006.

Wang, B., Bao, Q., Hoskins, B., Wu, G., and Liu, Y.: Tibetan Plateau warming and precipitation changes in East Asia, Geophys. Res. Lett., 35, L14702, https://doi.org/10.1029/2008GL034330, 2008.

Wang, Y., Ma, P.-L., Peng, J., Zhang, R., Jiang, J. H., Easter, R. C., and Yung, Y. L.: Constraining Aging Processes of Black Carbon in the Community Atmosphere Model Using Environmental Chamber Measurements, J. Adv. Model. Earth Sy., 10, 2514 2516, https://doi.org/10.1029/2018MS001387, 2018.

Wu, G., Liu, Y., Zhang, Q., Duan, A., Wang, T., Wan, R., Liu, X., Li, W., Wang, Z., and Liang, X.: The Influence of Mechanical and Thermal Forcing by the Tibetan Plateau on Asian Climate, J. Hydrometeorol., 8, 770-789, https://doi.org/10.1175/jhm609.1, 2007.

Yu, P., Toon, O. B., Neely, R. R., Martinsson, B. G., and Brenninkmeijer, C. A. M.: Composition and physical properties of the Asian Tropopause Aerosol Layer and the North American Tropospheric Aerosol Layer, Geophys. Res. Lett., 42, 2540-2546, https://doi.org/10.1002/2015GL063181, 2015.

Yu, P., Rosenlof, K. H., Liu, S., Telg, H., Thornberry, T. D., Rollins, A. W., Portmann, R. W., Bai, Z., Ray, E. A., Duan, Y., Pan, L. L., Toon, O. B., Bian, J., and Gao, R.-S.: Efficient transport of tropospheric aerosol into the stratosphere via the Asian summer monsoon anticyclone, P. Natl. Acad. Sci. USA, 114, 6972-6977, https://doi.org/10.1073/pnas.1701170114, 2017.

Zhang, Y., Chen, L.-L., Carmichael, G. R., and Dentener, F.: The Role of Mineral Aerosols in Tropospheric Chemistry, in: Air Pollution Modeling and Its Application XI, edited by: Gryning, S. E. and Schiermeier, F. A., Springer US, Boston, MA, 239-248, 1996. 